The Southeast Asian Journal of Midwifery Vol. 4, No.1, March, 2018, p: 1-7

E-ISSN: 2476-9720

P-ISSN: 2476-9738

\title{
Nutritional Status Associated with Menstruation Disorders
}

Fauziah Yulfitria $^{1}$, Ani Kusumastuti ${ }^{2}$, Erika Yulita Ichwan ${ }^{3}$

1,2,3 Poltekkes Kemenkes Jakarta III

\begin{tabular}{|c|c|}
\hline ARTICLE INFORMATION & ABSTRACT \\
\hline $\begin{array}{l}\text { Date of Submission: January 03, } 2018 \\
\text { Date of Revision: March 05, } 2018 \\
\text { Date of Publication: March 20,2018 }\end{array}$ & $\begin{array}{l}\text { Menstrual disorders such as delayed menstruation, irregular cycle, } \\
\text { menstrual pain, or hypermenorea can bring so much discomfort to } \\
\text { women caused by biological abnormalities and psychological }\end{array}$ \\
\hline $\begin{array}{l}\text { Keyword: } \\
\text { Nutritional status, menstruation } \\
\text { disorders } \\
\text { Contact: } \\
\text { zye_ajja@yahoo.com }\end{array}$ & $\begin{array}{l}\text { contributing to this disorder. This study aimed to determine the } \\
\text { relationship of nutritional status to menstrual disorders in } \\
\text { midwifery students. This descriptive analytical study used a cross } \\
\text { sectional study design and a correlation study to find the } \\
\text { relationship between the independent variables and dependent } \\
\text { variables. The samples were all the first grade students of } \\
\text { Midwifery Department of Poltekkes Jakarta Kemenkes III by } 150 \\
\text { people. Based on the bivariate test, there was a relationship } \\
\text { between nutritional status and polimenorea/oligomenorea (0.000), } \\
\text { hipermenorea/hipomenorea (0.006) and amhea ( } 0.001) \text {. The } \\
\text { lecturers of the midwifery program are expected to put more } \\
\text { concern on this problem by providing counseling about this issue } \\
\text { so that the students can get prepared to face the disorder by having } \\
\text { nutritional food in their daily life. }\end{array}$ \\
\hline
\end{tabular}




\section{INTRODUCTION}

Menstruation is a natural process that happens to every woman and usually first experienced around the age of 10 years. Menstruation is the process of discharge of blood from the inside of the uterus through the birth and women routinely occurred in each month during the period, unless those women experiencing pregnancy. Menstruation occurs due to the decay of the uterine wall due to the influence of the decrease in the hormone progesterone produced in ovaries (Najmi, 2011).

Menstruation is the periodic bleeding from the uterus that starts about 14 days after ovulation periodically due to the endometrial lining of the uterine terlepasnya. Long menstrual bleeding is due to menstruation. Normal menstrual 2-7 old days with intervals of two cycles. Normally blood comes out $60-80 \mathrm{ml}(2-4 \mathrm{x} / \mathrm{hr}$ change sanitary pad at the time of menstruation).

Delayed menstruation, irregular cycle, menstrual pain and bleeding a lot as well as the long form for menstrual disorders. Research Cakir $\mathrm{M}$ et al (Angularis, 2016) explains that the biggest disruption of menstruation is dysmenorrhoea $(89.5 \%)$, followed by menstrual irregularities $(31.2 \%)$ and the extension of the duration of menstruation $(5.3 \%)$. The results of research in East Jakarta concludes $91.7 \%$ of respondents experiencing menstrual disorders, of which $75.8 \%$ who experience premenstrual syndrome, a disorder long $25 \%$, and $5 \%$ who experience menstrual cycle disorders (Natin, et al, 2009 ).

Period which is susceptible to the onset of menstrual disorders are on the early years of menstruation. Approximately $75 \%$ of women suffered end teen disorders associated with menstruation (Anindita dkk, 2016). Menstrual disorders can be caused by an abnormality biologik and psikologik disorders. Other factors that can cause menstrual disorders are stress, nutritional status, age, and physical activity. Hormonal imbalances, the reproduction tool yet matur, psychic development and which is still labile cause adolescence more susceptible menstrual disorders.

Nutritional status of nutrient excess or less can cause the onset of menstrual disorders. This happens due to excess or lack of nutrition can interfere with the function of reproduction, ovulation function, changes in steroid hormone levels, as well as disorders of the maturation of the follicles that have an impact on menstrual disorders (Paath, 2014). Menstrual disorders can decrease the quality of life of women and interfere with daily activities. On workers in America, the number of attendance and the number of women per year income is lower than men's because women experience menstrual disorders (Herrmann et al MA 2012). In addition, the menstrual pain or disminorea in teens can cause a decrease in the ability to learn and even become the main reason that cause absences from school.

One more cause of menstrual cycle length is due to the increased amount of estrogen in the blood as a result of the increasing amount of body fat. Estrogen levels are high, this negative feedback against the secretion of GnRH. Based on preliminary studies conducted by interviewing college students majoring in nursing courses level I on the Poltekkes Jakarta Kemenkes III, from 23 students, 5 students ever experiencing menstrual disorders hipermenorea with a long duration, 3 college students experience polimenorea, and 5 people experience dysmenorrhoea.

\section{METHODS}

This research is descriptive analytic research. It is design to measure phenomena that occur without intervening against the variable. This research uses a correlation study to find the relationship between the free variables with variables bound in the form of the problem of menstrual disorders. The sample of this research are all level 1 students majoring in Midwifery Poltekkes Jakarta Kemenkes III 2016-2017 academic year which amounted to 150 people.

Data collection tools in this study is a questionnaire and examination sheets. Kuesinoer consists of questions about menstrual disorders in the shape of a closed question. Sheet collation consists of examination of weight using scales and height checks by using the tool to measure height. Data analysis using Univariate and bivariate. 


\section{RESULTS}

The results in this study are presented in some of the following table.

1. Univariate Analysis

Table 1: Respondent Characteristic

\begin{tabular}{llcc}
\hline \multicolumn{1}{c}{ Characteristic } & \multicolumn{1}{c}{ Variable } & F & \% \\
\hline Age & $<18$ & 86 & 57.3 \\
& $>18$ & 64 & 42.7 \\
Age of Menarce & $<13$ & 124 & 82.7 \\
& $>13$ & 26 & 17.3 \\
Nutritional & Low weight & 14 & 9,3 \\
status & Normal & 105 & 70.0 \\
& Over weight & 31 & 20.7 \\
& Total & 150 & 100 \\
\hline
\end{tabular}

Based on table 1, it shown that $57.3 \%$ of respondents aged $\leq 18$ years, $82.7 \%$ of respondents experienced menarche at age $\leq 13$ years, and $70 \%$ of the respondents were on normal nutrition.

Table 2: Menstruation disorder

\begin{tabular}{llcc}
\hline \multicolumn{1}{c}{ Categorv } & \multicolumn{1}{c}{ variable } & F & \% \\
\hline Menstrual & 1.Normal & 108 & 72.0 \\
cvcle & 2.Polv/Oligomerorea & 42 & 28,0 \\
Duration of & 1.Normal & 94 & 62.7 \\
haid. & 2.Hino/Hipermenorea & 56 & 37.3 \\
Dxsmenorhea & 1.No & 119 & 79.3 \\
& 2.ves & 31 & 20.7 \\
Amenorea & 1.No & 137 & 91.3 \\
& 2.Yes & 13 & 8.7 \\
Pre Menstrual & 1.No & 20 & 13.3 \\
Svndrom & 2.Yes & 130 & 86.7 \\
& TOTAL & 150 & 100 \\
\hline
\end{tabular}

Based on table 2 concerning respondents who experienced menstrual disorders, $28.0 \%$ experienced disruption cycle, $37.3 \%$ experiencing long menstrual disorders, $20.7 \%$ $8.7 \%$, disminorea experience experience amenorea, and $86.7 \%$ experienced pre-menstrual syndrome or PMS.

Table 3: Nutritional Status and Menstruation Cycle Disorder

\begin{tabular}{|c|c|c|c|c|c|c|c|}
\hline \multirow[t]{2}{*}{$\begin{array}{l}\text { Nutrion } \\
\text { al staus }\end{array}$} & \multicolumn{4}{|c|}{ Menstrual cvcle disorder } & \multicolumn{2}{|c|}{ Total } & \multirow[t]{2}{*}{$\begin{array}{c}\mathrm{p}- \\
\text { Value }\end{array}$} \\
\hline & $\mathrm{N}$ & $\%$ & $\mathrm{~N}$ & $\%$ & $\mathrm{n}$ & $\%$ & \\
\hline $\begin{array}{l}\text { Low } \\
\text { weight }\end{array}$ & 11 & 78.6 & 3 & 21,4 & 14 & 100 & \multirow{4}{*}{0.000} \\
\hline $\begin{array}{l}\text { Normal } \\
\text { weight }\end{array}$ & 87 & 82.9 & 18 & 17,1 & 105 & 100 & \\
\hline $\begin{array}{l}\text { Over } \\
\text { weight }\end{array}$ & 10 & 32,2 & 21 & 67.7 & 31 & 100 & \\
\hline Total & 108 & 72 & 42 & 28 & 150 & 100 & \\
\hline
\end{tabular}

In table 3, the respondents experienced a menstrual cycle disorders with details that $21.4 \%$ is with the nutritional status, $17.1 \%$ normal nutritional status, and $67.7 \%$ experiencing nutritional status was fat. The results of statistical tests show that $\mathrm{p}=0.000$ or $\mathrm{p} 0.05<$, meaning that there is a relationship between the nutritional status with disorders of the menstrual cycle.

Table 4: Nutritional status and Long Menstrual Disorders

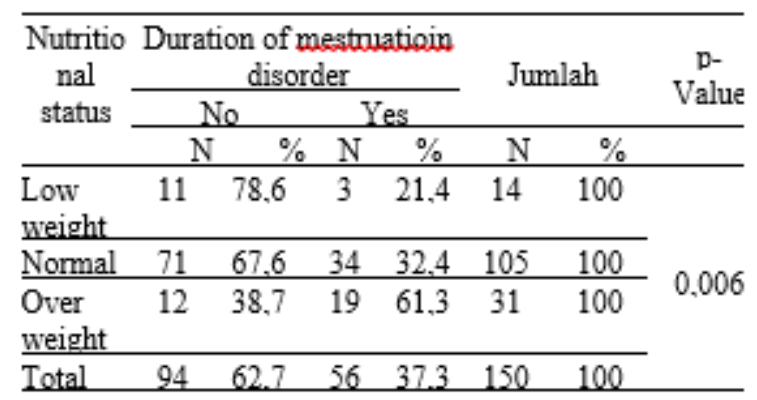

Table 4 showed that the respondents who experienced a long menstrual disorders, $21.4 \%$ of nutritional status, $32.4 \%$ experiencing normal nutrition, and $61.3 \%$ had nutrient status are obese. Test result statistics show $\mathrm{p}=0.006$ or $\mathrm{p}$ $0.05<$, meaning that there is a relationship between the nutritional status with longtime menstrual disorders.

Table 5: Nutritional status and Disminorea

\begin{tabular}{|c|c|c|c|c|c|c|c|}
\hline \multirow{3}{*}{$\begin{array}{l}\text { Dutrioti } \\
\text { onal } \\
\text { Status }\end{array}$} & \multicolumn{4}{|c|}{ Disminorea } & \multirow{2}{*}{\multicolumn{2}{|c|}{$\mathrm{N}$}} & p- \\
\hline & \multicolumn{2}{|c|}{ No } & \multicolumn{2}{|c|}{ ves } & & & Valu \\
\hline & $\mathrm{N}$ & $\%$ & $\mathrm{~N}$ & $\%$ & $\mathrm{~N}$ & $\%$ & \\
\hline $\begin{array}{l}\text { Low } \\
\text { weight }\end{array}$ & 11 & 78,6 & 3 & 21.4 & 14 & 100 & \\
\hline Normal & 84 & 80 & 21 & 20 & 105 & 100 & \\
\hline $\begin{array}{l}\text { Over } \\
\text { weight }\end{array}$ & 24 & 77,4 & 7 & 22.6 & 31 & 100 & 950 \\
\hline Total & 119 & 79.3 & 31 & 20.7 & 150 & 100 & \\
\hline
\end{tabular}

Table 5 shows the $21.4 \%$ had nutrient status of skinny, $20 \%$ is with the normal nutritional status, and $22.6 \%$ suffered nutritional status was fat. Test result statistics show $\mathrm{p}=0.950>$ or $\mathrm{p} 0.05$, which means that there is no relationship between the nutritional status with dysmenorrhoea. 
Table 6: Amenorhea and Nutritional Status

\begin{tabular}{|c|c|c|c|c|c|c|c|}
\hline \multirow{3}{*}{$\begin{array}{l}\text { Nutrioti } \\
\text { onal } \\
\text { Status }\end{array}$} & \multicolumn{4}{|c|}{ Amenorea } & \multirow{2}{*}{\multicolumn{2}{|c|}{$\mathrm{N}$}} & \multirow{3}{*}{$\begin{array}{l}\text { p- } \\
\text { Va } \\
\text { lue }\end{array}$} \\
\hline & \multicolumn{2}{|c|}{ No } & \multicolumn{2}{|c|}{ Yes } & & & \\
\hline & $\mathrm{N}$ & $\%$ & $\mathrm{~N}$ & $\%$ & $\mathrm{~N}$ & $\%$ & \\
\hline Low & 14 & 100 & 0 & 0 & 14 & 100 & \\
\hline Normal & 100 & 95,2 & 5 & 4.8 & 105 & 100 & 0,0 \\
\hline $\begin{array}{l}\text { Dver } \\
\text { Neight }\end{array}$ & 23 & 74,2 & 8 & 25,8 & 31 & 100 & 01 \\
\hline otal & 137 & 91.3 & 13 & 8.7 & 150 & 100 & \\
\hline
\end{tabular}

Table 6 Showed that the respondents who experienced amenorea, $4.8 \%$ had normal nutritional status and $25.8 \%$ shows the nutritional status was fat. Test result statistics show $\mathrm{p}=0.001$ or $\mathrm{p} 0.05$, so there are $<$ relationships between nutritional status with amenorea.

Table 7: Premenstrual syndrome with Nutritional Status

\begin{tabular}{|c|c|c|c|c|c|c|c|}
\hline \multirow[t]{3}{*}{$\begin{array}{c}\text { Nutritio } \\
\text { nal } \\
\text { status }\end{array}$} & \multicolumn{4}{|c|}{ Pre-Menstrual Svnabrom } & \multirow{2}{*}{\multicolumn{2}{|c|}{$\mathrm{N}$}} & $\begin{array}{l}\text { p- } \\
\text { Va }\end{array}$ \\
\hline & \multicolumn{2}{|c|}{ No } & \multicolumn{2}{|c|}{ Yes } & & & lue \\
\hline & $\mathrm{n}$ & $\%$ & $\mathrm{n}$ & $\%$ & $\mathrm{n}$ & $\%$ & \\
\hline $\begin{array}{l}\text { Low } \\
\text { weight }\end{array}$ & 1 & 7,1 & 13 & 92.9 & 14 & 100 & \\
\hline Normal & 11 & 10.5 & 94 & 89.5 & 105 & 100 & 0,0 \\
\hline $\begin{array}{l}\text { Over } \\
\text { weight }\end{array}$ & 8 & 25,8 & 23 & 74,2 & 31 & 100 & 68 \\
\hline Total & 20 & 133 & 130 & 867 & 150 & 100 & \\
\hline
\end{tabular}

Table 7 showed that the respondents who experienced pre-menstrual syndrom, $92.9 \%$ of less nutritional status, $89.5 \%$ are with normal nutritional status, and $74.2 \%$ have the status of nutritional fat. Test result statistics show $\mathrm{p}=$ 0.0680 or $p>0.05$ so that there is a relationship between the nutritional status with pre-menstrual syndrome.

\section{DISCUSSION}

The results of this study showed the majority of respondents aged $\leq 18$ years, i.e. as many as 86 people $(57.3 \%)$. This shows that respoden belongs to the youth. Adolescence is a transitional period between childhood and adulthood, is a 12-time identity search. Moreover, in adolescence, they experience physical and psychological growth of very rapid growth, including a reproduction appliance. They should get good information about the maintenance of reproductive health and, if they don't get the information, reproductive health problems likely will arise.

The majority of the age of menarche respondents were aged $\leq 13$ years, i.e. as many as 124 people $(82.7 \%)$. Menarche menstrual is the first to arrive and was as a sign of sexual maturity at teen Lady. At this time, women are expected to be able to do the right and proper care at reproductive tool, so the disruption on reproduction does not occur. Wiknjosastro dkk (2008) argues that menarche in adolescence occur at the age of 11-13 years. The age of menarche may be influenced by genetic, dietary, nutritional status, economic status, and sports activities.

In this study, the majority of respondents with normal nutritional status is as many as 105 people $(70 \%)$. Nutritional status is a State of health that are associated with the use of food by the body. One of the indicators that show has been the onset of balance of nutrients in the body is the achievement of normal body weight, i.e., the weight corresponding to body mass index. In early adolescence, adolescent attention toward body image began to appear. Fitrah women want to appear perfect and more than any other woman..

From the results of this research, several respondents experienced menstrual disorders, namely disorders of the menstrual cycle as much as $28 \%$, long menstrual disturbance as much as $37.3 \%$, disminorea as much as $20.7 \%, 8.7 \%$ as much, amenorea and pre-menstrual syndrome as much $86.7 \%$. Menstrual disorders are disorderabnormality in a State of menstruation can be a disorder of the blood that is ejected and duration of bleeding. Menstrual disorders can be caused by patologik conditions, lifestyle and psychological conditions

\section{Menstruation Cycle}

The menstrual cycle is the distance between the date of the beginning of menstruation with the beginning of the next menstruation with certain 
patterns each month. The menstrual cycle is considered irregular if it lasts 21-35 days, and is said to be irregular if progress $<21$ days (polimenorea) or $>35$ days (oligomenora). There are several factors that affect the menstrual cycle, such as age, diseases, genetic, reproductive tool, growth hormones, stress, use of contraceptives, nutritional status, and physical activity.

Chi-square test results indicate that there is a meaningful relationship between the nutritional Status with the menstrual cycle with $\mathrm{p}$ value 0.000. A woman who experienced a shortage or excess of nutrients will lead to a decrease in function of the hypothalamus so it can interfere with hipofisa anterior to produce FSH (Follicle Stimulating Hormone) and LH (Luteinizing Hormone). FSH stimulates the growth of functional follicular (follicle 3-30), each of which contains 1 egg while LH function in maturation or ovulation ovum (a phase of secretion) later if not fertilized will undergo decay (menstruation). When the production of FSH and LH is compromised, the menstrual cycle will also be disrupted. If every teenager has good nutritional intake with a good level of emotion that accompanied the lifestyle and good eating patterns, these things can affect the hypothalamus into either work so that the hypothalamus produces hormones which It takes the body especially reproductive hormones, and can be a regular menstrual cycle.

Menstrual bleeding with blood count more (80 $\mathrm{ml}>$ or replace the pads more than $5 \mathrm{x} / \mathrm{hr}$ ) and or the duration longer than normal ( $>7$ days) with a normal regular cycle called hipermenorea while hipomenorea is menstrual bleeding with fewer blood count $(50 \mathrm{ml}$ or replace $<$ bandage $<$ $2 \mathrm{x} / \mathrm{hr})$ and/or duration is shorter than normal $(<$ 3 days). Chi-square test results indicate that there is a meaningful relationship between the nutritional status with longtime menstrual $\mathrm{P}$ value of 0.006. According to Wolfenden (2010) in Hutami (2010), hormonal imbalance is the most influential factor in other obvious menstruation. Weight is a factor that can lead to disrupted hormone settings.

In women who are obese, women are not only androgen excess but also excess estrogen will result in frequent disruption of ovarian function so that it causes long menstrual disturbances (Hupitoyo, 2011). In women who are malnourished, a steroid hormone levels change. All sex hormones is a steroid. Under the stimulation of $\mathrm{LH}$, steroids is converted into the active compounds in androgenis by peripheral tissues. This will have an impact on changing the menstrual cycle and ovulation disorder (Paath, 2005).

\section{Dysmenorhea}

Dysmenorrhoea is one of menstrual disorders. Dysmenorrhoea have symptoms be the pain or discomfort in the lower abdomen or lower back, headaches, nausea, and fainting at the moment before or during menstruation. Chi-square test results indicate that there is no meaningful relationship between nutritional status by with disminorea with a value of P 0.950 .

\section{Amenorhea}

Amenorea is a State of no menstruation for at least three consecutive months at a reproductive age women who have experienced previous menstruation or a woman who has never been menstruating at the age of 16 years. From the results of this study, there is a relationship between the nutritional status with amenorea. More nutritional status, in addition to affecting organ growth, will also cause disruption of reproductive function. Nutritional status are not good can interfere with production of the hormones estrogen and progesterone and decrease production of Gonadotropin-releasing hormone $(\mathrm{GnRH})$ so that this inhibits the occurrence of ovulation or menstruation can affect the menstrual cycle. In women who are obese, they may experience a menstrual cycle disorders. It is associated with the amount of fatty tissues of the body. The fatty tissues of the body not only as storage of fat but also as a hormone-producing endocrine gland and target 
cells for a variety of hormones that the body's reproductive hormones, one of which (Devirahma, 2012).

\section{Pre-menstrual Syndrom}

From bivariate test results, there is no relationship between the nutritional status with pre-menstrual syndrom. This syndrome is a collection of physical symptoms and psychological changes that occur in the luteal phase of the menstrual and premenstrual subsided almost immediately. The symptoms started on day 5 to 10 th before menstruation, and the symptoms worsen during the ovulatory cycle. Another picture that often occurs is the symptoms eased 1 to 2 days before menstruation. (Anityio et al, 2009). Any of these symptoms in the form of physical and psychological disorders. Physical complaints are as painful or swollen breasts, bloating or abdominal pain, headaches, joint pain, back pain, nausea, vomiting, diarrhea or constipation, and the growth of skin problems such as acne. Psychic complaints include depression, sensitive, irritability, sleep disturbances, fatigue, weakness, and sometimes changes the mood very quickly.

The results of this study in accordance with the results of the research of Novita (2012) stating that there is no meaningful relationship between nutritional status with the incidence of Premenstrual Syndrome (PMS). However, every teenager daughters is expected to maintain a good nutritional status. The cause of PMS is unknown, but clearly there is clear suspicion, that an imbalance between estrogen and progesterone hormones. Estrogen and progesterone hormone imbalance is common on the process of menstruation.

\section{CONCLUSION}

Nutritional status associated with disorders of the menstrual cycle, menstrual disorders, and old amenorea. There is no relationship between the nutritional status with disminorea disorders and pre-menstrual syndrome. Health institutions expected to do health promotion in the form of guidelines or media making health an understandable and interesting, related to menstrual disorders.

\section{BIBLIOGRAPHY}

Anindita, dkk. 2016. Hubungan Aktivitas Fisik Harian dengan Gangguan Menstruasi pada Mahasiswa Fakultas Kedokteran Universitas Andalas. Padang ; Jurnal FK UNAND.

Anityo, dkk. 2009. Pengaruh Pemberian Vitamin B-Kompleks (B1, B2, B6, Kalsium Pantotenat, Asam Nikotinat) Terhadap Kejadian Sindroma Premenstruasi Pada Mahasiswa Prodi Kebidanan Magelang.

Devirahma, 2012. Hubungan Status Gizi Dengan Tingkat Perubahan Siklus Menstruasi Di SMK YPKK 2 Sleman (https://www.scribd.com/doc/8951530 1/BAB-I-Revisi-1).

Herrmann MA, et al. 2012. Do Menstrual Problems Explain Gender Gaps In Absenteeism and Earnings. Journal of Human Resourcess

Hutami, A.P. 2010. Hubungan sindrom pramenstruasi dengan Regularitas Siklus Menstruasi pada Mahasiswi S-1 Fakultas Keperawatan Universitas Sumatera Utara. Medan : Fakultas Kedokteran Universitas Sumatera Utara.

Hupitoyo. 2011. Obesitas dan Fertilitas, (online) (http://www.poltekkesmalang.ac.id/artikel -145- obesitas-dan-fertilitas.html, diakses: 22 April 2012)

Najmi. 2011. Buku Pintar Menstruasi. Jogjakarta ; Buku Biru.

Novita. 2012. Hubungan Status Gizi dengan Kejadian Premenstrual Syndrome (PMS) pada Remaja Puteri di SMP Negeri 3 Berastagi. Medan : Fakultas Keperawatan USU

Paath dkk. 2004. Gizi dalam Kesehatan Reproduksi. Jakarta ; EGC. 
Sabatia, dkk. 2011. Hubungan Tingkat Kecemasan dengan Perubahan Siklus Menstruasi pada Anak Kelas 12 di SMA Masehi Kudus. Kudus ; Jurnal Kesehatan dan Kebidanan AKBID.

Sianipar O, dkk. 2009. Prevalensi Gangguan Menstruasi dan Faktor-faktor yang berhubungan pada Siswi SMU di Kecamatan Pulogadung Jakarta Timur. Jakarta ; Majalah Kedokteran Indonesia.

Wiknjosastro. 2010. Ilmu Kebidanan. Jakarta; Yayasan Bina Pustaka Sarwono Prawirohardjo. 